\title{
Middlesex as a Bildungsroman: Cal/lie and the Problem of Identity
}

\section{Dr. Nina Sirkovic}

University of Split, Croatia

\section{Dr. Aleksandra V. Jovanovic}

University of Belgrade, Serbia

\section{Doi:10.5901/ajis.2013.v2n9p259}

\section{Abstract}

This paper analyses the novel Middlesex (2002) by Jeffrey Eugenides from the point of view of the Bildungsroman, considering moral, psychological, spiritual and social development and growth of the hero/ine from youth to maturity, whose desires and aspirations are in conflict with his/her environment and social order in the community. Regarding the Bildungsroman as a bond between (auto)biography and picaresque novel, Middlesex can also be considered as a Bildungsroman because of its specific narrative and the wanderings of the main protagonist from Detroit and San Francisco to Berlin. What makes Middlesex different from the classical Bildungsroman? During the process of development, the main heroine Calliope undergoes a unique change from a girl to a man, Cal, due to the impact of a mutated gene on three generations of an immigrant Greek family. Middlesex is a story about intersex where the protagonist, searching for her/his identity faces gender problem primarily within her/himself, and then with the community. The analysis of the inner life of the hero/ine and the struggle for his life mirrors the issues of the identity in the 21 century regarding the genre of the Bildungsroman.

Keywords: Bildungsroman, Middlesex, Greek immigrants, intersex, gender, identity

\section{Introduction}

Being originally a German subgenre, the Bildungsroman has spread and become one of the major novelistic forms in the Anglo-American literature. As the German word Bildung has various connotations (picture, portrait, shaping, formation), the term Bildungsroman had caused literary and scientific debates throughout centuries, which resulted in precise subcategorisation of specific types in German literature (Entwicklungsroman, Künstlerroman, Erziehungsroman), depending on the aspect of the development of the protagonist's character (Buckley, 1974, p. 13-14). Entwicklungsroman deals with the general growth of a hero, Künstlerroman is concerned with the growth and self-development of an artist, whereas Erziehungsroman refers mostly to educational aspect of the protagonist's self-growth.

In Anglo-American criticism definition of the Bildungsroman is more elastic and centred around the development of the protagonist's character. The hero is usually an orphan or a person coming from a poor provincial family, who, driven by the ambition to explore the world and find his/her own self, moves to a big city, learning and experiencing new life. Having gained knowledge and experience, the hero usually finds true love and is finally ready to share life with another person.

The Bildungsroman is sometimes interpreted as a bond between (auto)biography and picaresque novel. Since it started developing at the time of great popularity of confessional writing, it has many elements of a confession. Modern (auto)biography has also influenced the Bildungsroman and initiated the change in the narration, which turned from the third-person to the first-person narration. Although the Bildungsroman and autobiography describe the protagonist's development through her/his life, and have a similar narrative form, they differ in the abstraction of reality. In the Bldungsroman fact mingles with reality and at every moment this kind of a novel is fiction (p. 24). In autobiography the stylisation of life is not present; the author, narrator and the protagonist are the same. The autobiographer's writing is based on facts, whereas in novel, there is a real author, a fictional narrator and a fictional hero. The author in the novel admits to telling a fictional story, using autobiographical elements which contribute to the sense of reality, but it still remains fiction (Nübel, 2000, p. 471).

The hero of the Bildungsroman is like a picaro, s/he wanders from place to place, searching for new experiences. In the contrast to picaro, who just drifts around looking for an adventure, and who is more meditative, the protagonist of 
the Bildungsroman undergoes a process of personal development and maturity and his/her character forms synthesis till the end of the novel (Miles, 1974, p. 985).

Jeffrey Eugenides' Middlesex is a family saga describing three generations of Greek immigrants, from the first one fleeing from the poor village in Asia Minor to Detroit in 1922, over the second generation, which tries to assimilate and live as other Americans, to the third, whose member flees again, this time from America to Berlin, Europe. The family had its dark secret, namely, the first Stephanides', Desdemona and Leftie, who came to the USA as a married couple, are in fact brother and sister. In their incestuous relationship they had two children, Milton and Zoë, who were born as completely "normal" children, without any indications that their parents were of first kin. The problems started when their son Milton, who married his cousin Tessie, got his second child. After having a son, the couple desperately wanted a daughter. Following their uncle Pete's pattern on conceiving a daughter based on swift male and reliable female sperm, Tessie gave birth to Calliope, a baby girl.

If the old family doctor, Dr. Philobosian had properly examined the infant, the family would have been immediately informed about the anomaly of their child, but this was not the case. Thus Calliope was raised as a beloved beautiful girl until her puberty when her body started to develop in the strange way. Due to the 5-alpha-reductase deficiency, Callie's body did not produce dihydrotestosterone. She was born with external female genitals and was brought up as a girl, acting, thinking and looking as a girl. This lasted till her puberty when the other androgen, testosterone started to exert a strong effect on Callie's development: she grew very tall, got hairs over her face and body, changed her voice and consequently stopped being the lovely and sweet girl as she was before. After a car accident, Callie ended up in hospital and the secret started to unravel. She was taken to New York to the Sexual Disorders and Gender Identity Clinic where the most famous sexologist of the seventies tried to do her psychological assessment and define her gender identity.

Callie really wanted to be a girl because of her parents, so she deliberately faked the tests. As a consequence, Dr. Luce came to the conclusion that she was a girl and needed some cosmetic genital surgeries. Having read her medical file, in order to avoid the surgery and further humiliation, Callie decided to escape from the hospital and to live a life of his own. Leaving a note to his parents that he was a boy and felt like one too, Cal, who was fourteen, decided to go to California. After a long journey through many countries, he succeeded in coming to San Francisco and found a rather humiliating job in an erotic peep show club. Cal worked there among other "freaks" until he ended up in a prison after a police raid. When he phoned home, Cal learned that Milton had just died and this sad occasion brought him back home. Soon after, he applied for the post of foreign attaché assistant and got the job in which he could always be on the move a few years in one place and then moving to another. At the moment of telling the story, Cal lives in Berlin and has just started dating an Asian girl, a kind of social outcast too. The relationship is developing in the promising way, so it has a chance to become a true romance.

\section{Searching for identity}

Middlesex is a novel about the painful growing up of the protagonist who, above all, has to cope with the genetic history of his family. The journey of the mutated gene is the main reason for Cal's ambiguous identity, intensified by the family's desperate wish for a daughter, as well as with social expectations of the American and immigrant community. The novel starts with a confession:

I was born twice: first, as a baby girl, on a remarkably smogless Detroit day in January of 1960; and then again, as a teenage boy, in an emergency room near Petroskey, Michigan in August of 1974. (...) My birth certificate lists my name as Calliope Helen Stephanides. My recent driver's licence (...) records my first name simply as Cal. (...) But now, at the age of forty-one, I feel another birth coming on (Eugenides, 2003, p. 1-2).

Callie was brought up in a conservative family where the father was the wage earner and mother was a shy housewife, who never undressed in front of children and avoided "bodily matters". Puberty, usually a painful period for every teenager, was a big burden for Callie as she had no one she could turn to talk to. First she experienced physical changes. She was bad at sport because of her "problematic body". Her testicles, which Cal called "anarchists", had taken place in her abdomen and if she crossed her legs in the wrong way, or moved too quickly, she felt sharp pain. Instead of breasts, her hairs started to grow on her face and body and her entire appearance started to change. She grew tall, without any characteristic female signs, so she started faking having a period. From an Apollonian type of Greek (as Call paraphrases Nietzsche), a beautiful girl with a face ringed with curls turned into a Dionysian type: her delicate nose and eyebrows began to arch. She was no longer beautiful and grew long hair over her face to cover herself and started feeling as a "freak". There were seventies and it was a good time to be flat-chested, androgyny was "in", so this diminished a little the whole masculine picture of Callie. 
Apart from physical changes, different emotions started to appear. Callie found herself attracted to a female friend, which she called the "Obscure Object". The first sexual experience Callie had with Object's brother Jerome, after they all got drugged and drunk. This was a very painful experience, not just because she was forced into sex, but also from the physical side, namely, her internal organs were not developed as they are in women. Exposed as a "freak", Callie, at the age of fourteen, suffered pain, humiliation and rejection.

At the Sexual Disorders and Gender Identity Clinic, Callie suffered even more humiliation, she felt like "a living experiment". Her body was photographed, with her head covered in order to be published in medical books. Day after day Callie used to sit in the doctor's office, talking about her life, feelings, likes and dislikes and later wrote about them. She still had a sense of guilt, because her parents had always wanted to have the all-American daughter, so she kept on hiding her true feelings. She suffered another shock when she found the following explanation of the word "hermaphrodite" in the Webster's dictionary:

1. One having the sex organs and many of the secondary sex characteristics of both male and female.

2. Anything comprised of a combination of diverse or contradictory elements. See synonyms at MONSTER ( $p$. 430).

After the first reaction in tears and astonishment, this explanation opened Callie's eyes: she was aware that she would never be like other people and that the politeness and diminishing of her state was just hypocrisy from both doctors and her parents. Her faking the real state brought doctors to false interpretation of her sex. Suddenly, she decided to leave. There were two reasons for this decision: firstly, she did not want to embarrass her parents anymore and secondly, she was finally aware that she was more he and the surgery would not bring the unique identity. Callie felt more like a boy and started calling himself $\mathrm{Cal}$.

Cal was aware of his androgyny. After he changed female clothes into male and had his hair done, he looked at himself in the mirror:

And in the mirror I didn't see myself. (...) Not the shy girl with the tangled black hair in her face, but instead her fraternal brother. With the screen of my hair removed, the recent changes in my face were more evident. My jaw looked squarer, broader, my neck thicker, with a bulge of Adam's apple in the center. It was unquestionably a male face, but the feelings inside that boy were still a girl's. To cut up your hair after a breakup was a feminine reaction (p. 445).

Although he felt more like a boy, Call did not feel entirely at home with men, he never fell out of place being a girl. His searching for his real self brought him to San Francisco among other people with similar problems: to earn for living, he found a job in a kind of a grotesque peep-show club called "Octopussy's garden". Cal was presented as the "God Hermaphroditus, half man - half woman" and swam in a tank with water exposing himself to voyeurs. His colleagues were transvestites, transsexuals and similar people who were rejected by the society because of their looks and sexuality. He felt safer and freer among them, although they were drunk and drugged before every performance, bored and unhappy, knowing they were exploited and humiliated and considered freakish.

At the present moment, being aware of himself, Cal knows he could not have children and this is one of reasons he never married. This is also one of the reasons he joined the Foreign Service. As a diplomat, he could always be on the move, never stay in one place. Currently he is in Berlin and this once-divided city reminds him of himself. He is still shy and has revealed his secret only to a few friends. Sometimes, when he feels lonely, he tells his story to an unknown person in a bar, otherwise he keeps silent forever.

When he meets a woman he is attracted to and when she likes him, it usually ends in "incomplete seduction", it all stops at drinks and dinners. He leaves, making an excuse. Recently he has met an Asian girl who seems to understand him and perhaps a true romance could happen between two of them.

The conformism at the end, usually present in the Bildungsroman is obvious in this novel, too: Cal deliberately runs from relationships changing places to live, he does not want surgery since he feels it will not solve his problem of intersex. He gets close to people up to a point and when he should approach them, he decides to run away.

Also, despite having an androgynous mind, Cal claims he is not androgynous in the least. He feels like a male. In society he operates as a man. Although he has lived more than half of his life as a male, sometimes Calliope surfaces, bringing girlish emotions with herself and Cal feels possessed:

Callie rises up inside me, wearing my skin like a lose robe. She sticks her little hands into the baggy sleeves of my arms. She inserts her chimp's feet through the trousers of my legs. On the sidewalk l'll feel her girlish walk take over, and the movement brings back a kind of emotion, a desolate and gossipy sympathy for the girls I see coming home from school. (...)The sick fluid of adolescent despair that runs through her veins overflow again into mine. But then, just as suddenly, she is leaving, shrinking and melting inside me, and when I turn to see my reflection in a window, there's this: a forty-one-year-old man with longish, wavy hair, a thin moustache, and a goatee. A kind of modern Musketeer (p. 42). 


\section{Cal as a modern picaro and his confession}

As a picaro in a picaresque novel, Cal was always on the move from his fourteenth year. After his escape from the hospital in New York, he did not return to his home town Detroit, but travelled across Ohio, Indiana, Illinois, lowa and Nebrasca to California, San Francisco. His choice of a diplomatic post brought him to another continent, to Berlin, which still does not seem to be his last stop. Picaro moves from one place to another in timeless eternity, the episodes recount his adventures; hence history can gain endless dimensions. In the Bildungsroman the narrator is distanced from the hero and his/her life. The time in the Bildungsroman is not chronological and readers can follow the formation of the hero's character through reflections and memories of the past (Sirković \& Bilić, 2008, p. 365). In the novel Middlesex, present and past interfere, Cal retells stories from the past from the present point of view, commenting and explaining them from the present experience.

What is the narrative structure of Middlesex? The omniscient author tells the story in two, or three voices: the thirdperson voice which retells the stories from the past, mostly the events concerning Cal's grandparents and parents, then Callie's voice and finally Cal's voice, which two sound same. It seems that Eugenides concerned Callie and Call as having the same narrative voice. Despite Cal's changes in appearances and behaving as a male, their mode of thinking remains the same. However, it is notable that sometimes Cal's telling in the first-person narrative switches to the thirdperson when talking about Callie - the author emphasizes that Cal wanted to distance himself from Callie. For example, the episode in which Callie discovered the word "hermaphrodite" in Webster's dictionary is told in the first-person (meaning, Cal tells the story), but when describing Callie's first reactions on the chain of similar words, the narrative switches to the third-person:

Callie herself was holding on to this chain now. She was tugging on it, winding it around her hand, so that her fingers went white, as she stared down at that word. Monster. (...) That was what she was (Eugenides, p. 431).

The switching from the first-person, meaning personal, to the third-person, in this case external, points out to Callie's final discovery of her state. She thought she was objectively considered as a monster, but from the present situation, Cal distances himself from that judgement.

In many situations, the omniscient author tells the story in an ironic way and anticipates future events. This is particularly obvious in retelling the prefetal period of Cal/lie's life in terms of his/her genes. When describing the dialogue between Tessie and Milton about techniques of conceiving a daughter, the narrator says: "Of course, a narrator in my position (prefetal at that time) can't be entirely sure about any of this" (p. 9). A little later, he anticipates his coming to the world: "Meanwhile, in the greenroom of the world, I waited" (p. 11).

The history of the family deeply influenced the formation and development of Cal's character, which he confirms at the beginning of the novel:

All I know is this: despite my androgenised brain, there's an innate feminine circularity of the story I have to tell. In any genetic history: I'm the final clause in a periodic sentence, and that sentence begins a long time ago, in another language, and you have to read it from the beginning to get to the end, which is my arrival ( $p .20)$.

The omniscient author plays with readers telling stories from Cal's prefetal and prenatal phases, then getting into other characters' minds, and finally, following both Callie's and Cal's thoughts and commenting their acting. He often reveals present situation and then goes back to the past to explain how something had happened. Nevertheless, it does not diminish the suspense of the story. The narrator is not judgemental and shows understanding for the hero as well as for other characters and sympathises with Cal/lie's painful experience and journey to his identity.

\section{Conclusion}

The story of the development of the protagonist's character from youth, in this case from birth to maturity, tracing his conflict with the environment and social rules, as well as common issues with the autobiographical and picaresque novel, make this novel a Bildungsroman. Middlesex is a story about intersex where the protagonist, being born as a hermaphrodite man, but from his birth mistaken for a girl, faces gender problem which he has to solve primarily within himself, and then with the community. Throughout the novel, Cal searches for his identity through painful experiences and maturing processes, finally accepting a kind of conformity in order to fit into the community. Proper integration is not possible and, being aware of it, Cal chooses a job which enables him to change places every few years, so he does not have to make intimate friendships and relationships. He remains a lonesome person with a secret, but he can live with it, he has gained self-confidence and has courage and strength to be an equal member of society. 


\section{References}

Buckley, J. H. (1974). Season of youth: the Bildungsroman from Dickens to Golding. Cambridge: Harvard UP.

Eugenides, Jeffrey. (2003). Middlesex. Bloomsbury. London. Berlin. New York. Sydney.

Miles, David H. (1974). "The picaro's journey to the confessional: the changing image of the hero in the German Bildungsroman“. In: PMLA 89. Pp 980-992.

Nübel, Birgit. (2000). „Autobiografski komunikacioni mediji oko 1800. godine“. In: R.E.Č. Časopis za književnost, kulturu i društvena pitanja. Nr.60.5. Beograd. Samizdat Free B92.

Sirković, Nina, Matić Bilić, Mirjana. (2008). „Goethe's Wilhelm Meister and Virginia Woolf's Orlando through the prism of the Bildungsroman". In: ELLSSAC Proceedings, Volume II. Faculty of Filology. University of Belgrade. Belgrade. Pp. 363-373. 